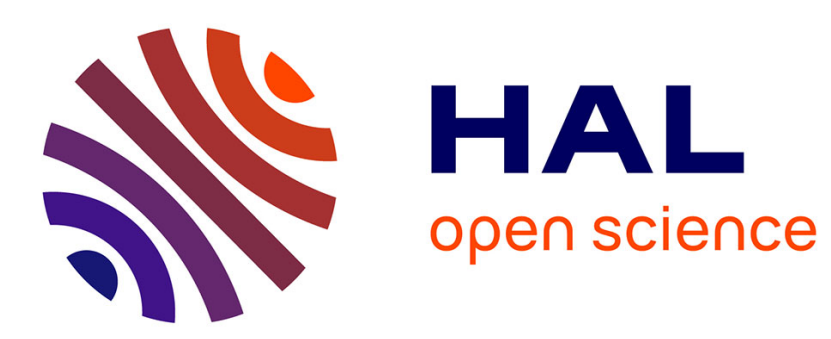

\title{
New and on-going challenges for structural engineers regarding existing structures \\ Bruno Godart
}

\section{To cite this version:}

Bruno Godart. New and on-going challenges for structural engineers regarding existing structures. Structural Engineering International, 2017, 27 (4), p 481. 10.1080/10168664.2017.11985661 . hal02569694

\section{HAL Id: hal-02569694 \\ https://hal.science/hal-02569694}

Submitted on 11 May 2020

HAL is a multi-disciplinary open access archive for the deposit and dissemination of scientific research documents, whether they are published or not. The documents may come from teaching and research institutions in France or abroad, or from public or private research centers.
L'archive ouverte pluridisciplinaire HAL, est destinée au dépôt et à la diffusion de documents scientifiques de niveau recherche, publiés ou non, émanant des établissements d'enseignement et de recherche français ou étrangers, des laboratoires publics ou privés. 


\title{
Editorial for SEI Journal
}

\author{
New and on-going challenges for structural engineers regarding existing \\ structures
}

\author{
Bruno Godart, \\ Deputy-Director of the Materials and Structures Department at IFSTTAR \\ Marne-la-Vallée (France)
}

Considering the level of infrastructure development achieved in many developed countries, works conducted in the field of civil engineering will increasingly focus on the maintenance and repair of structures. The maintenance of existing structures will therefore become an significant challenge, whether for infrastructure managers, who will have to improve their management methods, or for companies that will have to carry out works under specific, and sometimes difficult conditions, or for the structural engineers who will have to design and plan innovative solutions. Concerning this last point, we could mention, as an example, the development of the so-called, somewhat caricatured term "stealth work sites". This term refers to construction on sites that will increasingly have to be carried out with the least possible interference to the operation of the structure, and which will require imaginative approaches in order to find solutions adapted to the severe operation constraints of certain road and railway infrastructures, particularly in urban areas.

In addition, accidental actions such as earthquakes, floods and cyclones will pose an increasing number of questions to the structural engineer, both in the design of new structures and in the dimensioning of cost-effective strengthening of existing structures. The considerable destruction that occurred on the islands of St-Martin and St Barthelemy during the very recent passage of the IRMA hurricane (95\% of the existing building stock was destroyed or damaged) remind us that reinforcement is necessary so that existing structures can withstand exceptional climatic events, the frequency of which is unfortunately likely to increase in the future (a displeasing fact for some climatic skeptics ...). The collapse and destruction of structures should also favor the development of forensic engineering based on all the methods and techniques applied to the investigation in order to analyze and understand the origin of the disasters, and draw lessons from them. It seems that lessons from failures have not sufficiently been drawn on in the past and one of the solutions consists in significantly reinforcing the teaching of the pathology of structures and forensic engineering at universities and schools, teaching which appears to still be very weak in most countries.

Another challenge awaits the structural engineer in the management of existing structures. This involves the assessment and detailed evaluation of structures with specific material pathologies such as internal swelling of concrete, freeze-thaw damage, corrosion of rebar in reinforced concrete, fatigue of metal or deterioration of wood. Collaboration with material scientists will be essential to move forward on advanced models and numerical calculations that allow for safety, serviceability and durability limit state checks, and facilitate the design of reinforcements adapted to increase the lifespan of structures. 
The challenge ahead is therefore to evaluate and maintain our heritage of existing buildings and civil engineering structures, while enhancing and modernizing it to make it safer and more sustainable. 